\title{
Öngörülemeyen Bir Küresel Düzen ve Covid-19: Covıd-19 Karikatürleri ile Yeni
} Düzen Okuması

\section{An Unpredictable Global Order and Covid-19: An Analyzes of the New Order Through the Covid-19 Cartoons}

Fatih Fuat TUNCER ${ }^{\mathrm{a} *}$

${ }^{a}$ Dr. Öğretim Üyesi, İstanbul Gelişim Üniversitesi, İstanbul / TÜRKIYE

ORCID: 0000-0002-4034-5949

\section{A K A L E B İL G İ S İ \\ Makale Geçmişi: \\ Başvuru tarihi: 5 Haziran 2020 \\ Kabul tarihi: 15 Haziran 2020}

\section{Anahtar Kelimeler:}

Uluslararası Politika,

Küreselleşme,

COVID-19,

Karikatür,

Uluslararası İlişkiler

\section{A R T I C LE INFO}

\section{Article History:}

Received June 05, 2020

Accepted June 15, 2020

\section{Keywords:}

International Politics,

Globalization,

COVID-19,

Cartoons,

International Relations

\section{ÖZ}

COVID-19 pandemisi ile birlikte dünya yeni bir gerçekliğin içerisine düşmüş ve Soğuk Savaş sonrası 'yeni gerçek’ olarak kabul edilen her şeyin sorgulandığı görülmüştür. Yıkılmaz kale olarak görülen küreselleşmenin birçok kez sınavdan geçtiği son otuz yılda küreselleșme, ilk kez bu kadar ciddi bir sınav ile karșı karșıyadır. Küreselleşmenin etkisinin artması ile ortaya çıkan ‘yeni düzen' ve 'yeni düzensizlik' tartışması, pandemi süreci ile birlikte yeniden alevlenmiștir. Tüm dünyanın tek gündemi haline gelen COVID-19, en eski iletișim mecralarından biri olan karikatür dünyasının da ana gündem maddesi olmuştur. Bağımsız karikatüristlerin öngörülemeyen bu yeni küresel düzeni eleştirel bir bakış açısı ile ele aldıkları görülmektedir. Küresel ekonominin aslında ne kadar dayanıksız olduğunu aktaran karikatüristler, siyasilerin ikiyüzlü ve popülist davrandıklarını okuyucuları için çizmekte ve eserlerinde küresel düzenin geleceğini sorgulamaktadırlar. Küreselleşmenin getirdiği risk sonucu ortaya çıktığı tartışılan pandeminin en büyük olumsuz etkisinin küresel düzenden faydalananlara değil sokaktaki insana ve topluma etkisi olduğu gerçeği de karikatüristler tarafindan vurgulanmaktadır.

\begin{abstract}
A B S T R A C T
With the pandemic of COVID-19 the world has fallen into the grasp of a new reality and everything accepted as "new truth" after the cold war.has been questioned. Globalization once seemed an impenetrable fortress, has faced many battles in the past thirty years however this one seems the hardest. The discussion about "new order" and "new orderlesness" have once more fueled by the pandemic. COVID-19 which has been the focal point of discussions across the world have also become the the subject matter of caricatures, one of the oldest mediums of media. Independent cartoonists seem to be criticizing this unforeseen new global order. Cartoonists elaborate the weakness of the global economy, while underlining the hypocrisy and the populism of the politicians and question the future of the global order. The pandemic, which is a result of globalization, has affected the average person rather than the people who benefit from globalization and this has been emphasized by the cartoonists.
\end{abstract}




\section{EXTENDED ABSTRACT}

People who have been discussing the new global order, claim that people have come together for the first time since the tower of Babylon. The process we are going through seems unclear; on the one hand there are discussions about a vaccine on the other hand the effect that the current situation had on social, political and economic life. Destruction hastened by globalization, common problems and deepening deadlock has become the biggest test. In our world where everything is affected by globalization, faces a wave of global unemployment and crisis. Commentators discuss what this process results with whereas the common man has a simpler agenda, to protect him and his family, because for humankind the state, the international bodies and technology are all new. Humankind has been acting on survival instinct for centuries and this time is no expception.

While it is claimed that globalization has brought the end of the nation state, it is true that it has encountered many resistances until today. The economic crisis, which started in Asia in 1997, moved to Russia and deeply affected the economies of the developing countries, and then the world financial markets, and disturbed the global financial markets in the world. It was observed that the rebounding financial markets were shaken again with the global crisis in 2008 . It is known that the aftershocks of the 2008 crisis brought Greece to "bankruptcy". If the nation-states always offer the solution in all these crises, is "the nation-state still our only guarantee?" caused the question to be asked again. The importance of nation-states, which has been forgotten after each crisis, has come to the forefront again today. It has become an epidemic that started from China at the end of 2019 and spread to the World and marked the first five months of 2020. This new COVID-19 (new type of Corona Virus) situation, which has put the whole world in an unprecedented crisis socially, economically, and politically, has restarted the 'new order' discussions. The whole world now has one agenda: COVID-19. In this process, it seems that there is no country in which the virus does not spread. Now, the headlines of all the newspapers, the main subject of the columns and the only agenda of television programs seem to consist of this virus. The world has learned the answers to questions such as how to wash hands and protect ourselves. However, there is only one question in mind: "what about the world order from now on?"

The 'world order after COVID-19' has become the most popular discussion in the world today. Politicians, economists, sociologists, and the average people have no other agenda, and they all discuss what will happen next. "Nothing will be the same after this" is the most popular discourse. However, what will happen next is quite controversial. While some authors say that global markets will not be the same with COVID-19, some authors say that people's habits will change. However, everyone agrees that what the real issue of the people on the street is to provide for the state, which is authorized by the "social contract". In the COVID-19 process, it is seen that nation-states are not actually worn out and on the contrary, are the first actors to come to mind in real crisis moments.

It is argued that the COVID-19 pandemic is more shocking than any crisis in the global world over the past 30 years. No one has an idea about when the crisis will end, resulting in speculation scenarios for the future. With pandemic, fear also increases rapidly, and the uncertainty that emerges frightens both the people and the global system that is believed to function flawlessly after the Cold War, and somehow overcame every crisis that came before it. Nation states, which have been claimed to be eroding with globalization and perhaps disappear over time, seem to be the only structure trying to prove their existence with this crisis. The most important reason why nation states come to the fore in this crisis is the international system's drift into uncertainty, namely chaos, together with the pandemic. Because today, an international cooperation against the crisis has not been developed. It is noteworthy that the concept of "European Dream", which was built with the European Union, was opened to discussion and the union could not be a "union" against the crisis. In this process, the COVID-19 pandemic has become a vital test for both national and transnational institutions.

Whereas the history of states and globalization is rather new for humanity, caricature moves into the same direction simultaneously with the history of humanity. The caricature, which can be considered as the first artistic initiative of humanity, first came to life on the cave walls and rocks and transferred the current agenda, lives, problems, and solutions of humanity to thousands of years later. Cartoons are much more than laughs, even though they are simplified as "laughing" today. The cartoon, which continues to exist throughout the history of humanity with what it thinks and feels, is an enormous resource to be able to make a historical reading of each period. Because a cartoon can tell people what is written on hundreds of pages and what is told for hours in a simple way with a single drawing. For this reason, it is possible to evaluate the cartoon as one of the most efficient and important means of thought transmission. In the COVID-19 process, humanity faces an incomprehensible information bombardment. Despite this much information and resources, cartoons are the only medium that can summarize the process. This study aims to analyse the process that the world goes through with the COVID-19 epidemic through cartoons published across the world. For this purpose, descriptive analysis method, which is one of the qualitative research methods, will be used, and the language, meanings and functions of the cartoons published in the world media about COVID-19 will be discussed in order to understand the real agenda of humanity. The study will consist of four main sections, including the introduction. In the second part, the discussion of 'globalization and new order' will be discussed, and in the third part, the place and importance of the cartoon in human history will be evaluated under the title of 'cartoon and its importance' and finally, in the fourth part, the analysis of the order of COVID-19 will be conducted through cartoons. 


\section{Giriş}

"Yaşam, düşünenler için bir komedi, hissedenler içinse bir trajedidir"1.

COVID-19'un bu kadar etkili olması ile birlikte küreselleşme üzerine çalışanlar, küreselleşmenin bizi getirdiği noktayı işaret ederek, belki de Babil Kulesi'nde ayrılan insanların ilk kez yeniden 'aması/fakatsız' bir araya gelmek zorunda olduklarını iddia ediyorlar. İçinden geçtiğimiz süreç ise belirsiz; bir yandan aşının ne zaman bulunacağ tartışılırken, bir yandan da bu sürecin dünyaya sosyal, siyasal ve ekonomik etkisi tartış1lıyor. İnsanlığın post modern Babil Kulesi olan küreselleşme ise bu her şeyin bulanık göründüğü süreçte o meşhur 'hızlanma, yaygınlaşma ve derinleşme' etkisi ile soruna çare olmak bir yana sorunun sebebi oluyor. Küreselleşme ile hızlanan tahribat, yaygınlaşan sorunlar ve derinleşen çözümsüzlük, bugün tarihteki en büyük sınavını veriyor. Her şeyin küreselleştiği dünyamızda insanlık, küresel bir karantinada, küresel bir işsizlik ve küresel bir ekonomik kriz dalgası ile karşı karşıya bulunmaktadır. Yorumcular televizyonda bu sürecin neler getirip neler götüreceğini tartışırken, sokaktaki insanın gündemi ise çok daha basittir: kendini ve ailesini bu süreçte korumak. Zira insan ırkı için devletler de uluslararası kurumlar da teknoloji de yenidir. İnsanoğlu binlerce yıldır hayatta kalma güdüsü ile hareket eder ve ona göre pozisyon alır.

Devletlerin ve küreselleşmenin tarihi insanlık için oldukça yeni iken karikatür ise insanlık tarihi ile eş zamanlı ilerlemektedir. İnsanlığın ilk sanatsal girişimi olarak değerlendirilebilecek karikatür ilk olarak mağara duvarlarında ve kayaların üzerinde hayat bulmuş ve insanlığın o anki gündemini, hayatlarını, sorunlarını ve çözümlerini binlerce yıl sonraya aktarmıştır. Karikatür, günümüzde 'gülmece' olarak basite indirgense de gülmekten çok daha fazlasıdır. Düşündürdüğü ve hissettirdiği ile insanlık tarihi boyunca var olmayı sürdüren karikatür, her dönemin tarihsel bir okumasını yapabilmek için muazzam bir kaynak özelliğini taşımaktadır. Zira karikatür, yüzlerce sayfada yazılanları ve saatlerce anlatılanları basit bir şekilde, tek bir çizimle insanlara anlatabilmektedir. Bu nedenle karikatürü en verimli ve önemli düşünce iletim araçlarından biri olarak değerlendirmek mümkündür. COVID-19 sürecinde insanlık anlaşılamayan bir bilgi bombardımanı ile karşı karşıyadır. Bu kadar fazla bilgi ve kaynağa rağmen yaşanan süreci basitçe özetleyebilen tek mecra ise karikatürlerdir. Bu çalışma da dünyada yayınlanan karikatürler üzerinden COVID-19 epidemisi ile birlikte dünyanın içinden geçtiği süreci analiz etmeyi amaçlamaktadır. Bunun için de çalışmada nitel araştırma yöntemlerinden betimsel analiz yöntemi kullanılacak, insanlığın gerçek gündemini anlayabilmek için COVID-19 ile ilgili dünya medyasında yayınlanan karikatürlerin dili, anlamları ve işlevleri ortaya konulacaktır. Çalışma, giriş bölümü dâhil dört ana bölümden oluşacaktır. İkinci bölümde 'küreselleşme ve yeni düzen' tartışması ele alınacak, üçüncü bölümde 'karikatür ve önemi' başlığı altında karikatürün insan tarihindeki yeri ve önemi değerlendirilecek ve son olarak dördüncü bölümde de COVID-19 düzeninin karikatürler üzerinden analizi yapılacaktır.

\section{Küreselleșme ve Yeni Düzen Tartışması}

Ticaretin ve kültürel değişimin kitlesel olarak artması ile dünyanın giderek küçülmesi, 'küreselleşme' olarak ifade edilebilmektedir. Küreselleşmenin ne olduğunu tartışmak yerine önce küreselleşme kavramının oldukça popüler olduğunu kabul etmek gerekiyor. Zygmunt Bauman'ın (1998) dediği gibi; herkesin dilinde olan bu sözcük hızla bir parolaya, sihirli bir sözcüğe ve tüm gizemin kapısını açacak bir anahtara dönüşüyor. Ancak bugün gelinen noktada küreselleşme, kimilerine göre onsuz nefessiz kalacağımız bir gerçek iken kimilerine de göre bugün yaşanan tüm sorunların tek nedenidir (Bauman, 1998, s. 7). Bauman'ın vurguladığı bu

\footnotetext{
${ }^{1}$ Horace Walpole, Sanat Tarihçisi.
} 
ikiliğe Robert J. Samuelson (2000) da küreselleşmeyi ‘iki ucu keskin bir biçak’ benzetmesi ile destek verir. Samuelson ve Bauman'ın da belirttiği gibi küreselleşmenin iyi ve kötü olmak üzere iki tarafı vardır. Samuelson, The New York Times gazetesinde yayınlanan "21. Yüzyıla Geleceğe Bakış" yazı dizinde bu durumu şu şekilde ifade etmektedir:

Yeni yüzyılın kenarında, küreselleşme iki ucu keskin bir kılıçtır: ekonomik büyümeyi arttıran, yeni teknolojiyi yayan ve zengin ve fakir ülkelerde yaşam standartlarını artıran güçlü bir araç iken aynı zamanda da ulusal egemenliğe saldıran, yerel kültür ve gelenekleri, ekonomik ve sosyal istikrarı tehdit eden son derece tartışmalı bir süreçtir. (Samuelson, 2000).

Küreselleşme, insanlık tarihinden bu yana devam eden bir süreç olarak yorumlanabilse de Neil Irwin'e (2018) göre tarihsel durum böyle değildir. Zira küreselleşme, zaman zaman uyumakta/durmakta ve yeniden başlamaktadır (Irwin, 2018). Küreselleşmenin bu denli hayatımızda yer işgal etme hali veya Irwin'in sözünü ettiği 'yeniden başlama' hali ise hiç kuşkusuz ki Soğuk Savaş'ın bitişi ile ortaya çıkmıştır. Ancak bu yeni başlangıç tarihteki öncüllerinden çok farklıdır. Dünyadaki ideolojik kutuplaşmanın kalkması ile bir anda ortaya çıkan 'sürekli büyüme hedefi', aslında bir nevi yeni düzenin nasıl olacağının işaretlerini veriyor gibi idi. Küresel sermaye ve finans piyasalarını birbirine sıkıca bağlayan bu hedef, insanlığın düzenini de değiştiriyordu. Birbirine bağlanan sadece piyasalar olmuyor, tek kültür ve tek tip insanın tartışıldığ 1 yeni bir döneme giriliyordu. Bu yeni dönem ise bir yandan 'tarihin sonu' olarak liberal ve kapitalist düzenin zaferi şeklinde olumlu yorumlanırken diğer yandan da 'küresel bir risk toplumu' inşa edeceği kuşkusunu ortaya çıkarıyordu. Var olan kötü düzenin sonunun geldiğini müjdeleyen Francis Fukuyama (1989), bundan sonra Batı'nın düzeni ve demokrasinin dünyaya hâkim olacağını, insanlığın son ve yenilmez aşamaya geçtiğini vurguluyordu (Fukuyama, 1989, s. 3-18). Ulrich Beck (1992) ise Soğuk Savaş sonrası süreci, Fukuyama gibi olumlu karşılamamakta ve yeni düzenin bir küresel risk toplumu ortaya çıkarabileceği uyarısını yaparak insanları ön görülemez ve tahmin edilemez risklere karşı uyarır (Beck, 1992, s. 21).

Soğuk Savaş'ın tozu dumanı yeni dağılıyorken ortaya çıkan 'yeni düzen' tartışması, küreselleşme kavramı ile birlikte yeni bir boyut kazanmıştır. Çünkü 'hiçbir şeyin eskisi gibi olmayacağı' noktasında küreselleşme taraftarları da karşıtları da uzlaşmış gibi görünmektedir. Ancak bu durum, kimine göre 'yeni dünya düzeni' olarak yorumlanabilecek iken kimine göre de 'yeni dünya düzensizliği' olarak yorumlanabilecektir. İlk olarak Ken Jowit'in (1992) ifade ettiği bu yeni düzensizlik durumu vurgusu dikkat çekicidir. Noam Chomsky (2003) de 'yeni dünya düzeni' denilen şeyin bir düzen değil tam tersine bir düzensizlik getirdiğini vurgulayarak bu yeni düzenin güce ve sömürüye dayandığını vurgulamaktadır. Chomsky, yeni düzenin düzensizliğini belki de Fukuyama'ya bir cevap niteliğinde şu şekilde anlatır:

Yeni Dünya Düzeninde dünya, zenginler tarafından ve zenginler için yönetilir. Dünya sisteminin klasik bir piyasayla hiçbir alakası yoktur; 'şirket merkantilizmi' terimi bu sisteme daha iyi uyar. Yönetim gitgide dev özel kuruluşların ve temsilcilerinin ellerinde toplanıyor. Bu kurumlar totaliter niteliktedir: Bir şirkette iktidar yukarıdan aşağıya iner, dışardaki halk dışta bırakılır. 'Serbest girişim' diye bilinen diktatörlük sisteminde, yatırım kararları, üretim ve ticaret üzerindeki iktidar, merkezi ve kutsaldır, bir ilke ve hukuk meselesi olarak işçilerin ve toplumun etki ve kontrolünden bağışıktır (Chomsky, 2003, s. 270).

Chomsky, küreselleşme denen şeyin getirdiği dünya düzeninin birilerinin yani 'en eşit' olanların düzeni olduğunu söylemektedir. Aslında Chomsky, Soğuk Savaş sonrası maruz kaldığımız küreselleşme reklamının yeni bir düzen getirmediğini aslında tam da Batı'nın geçmişteki politikasının bir devamı olduğunu belirtmektedir. 2000'li yıllar ise Soğuk Savaş sonrası söylenenlerin ve beklentilerin doğru çıkmadığı ancak küreselleşme sevdasının ve söyleminin son hız devam ettiği yeni bir yüzyılı karşılıyordu. Geçmiş yüzyılların mirası olan savaş ve işgal, 2000'li yıllarda Ortadoğu'da kendisini gösterirken, küreselleşme hareketi hız kesmeden devam edecekti. Küreselleşme ile birlikte yeni bir kitle kültürünün de oraya çıktığ 1 görülmektedir (Akova, 2016, s. 1601). Küreselleşme ile birlikte dünyanın tek bir mekân olarak 
tasavvur edildiği ve 'küresel köy' yaklaşımının da ön plana çıktığı görülmektedir. Mcluhan'ın ortaya attığı bu 'küresel köy’ kavramını Yakup Çoştu (2005), şu şekilde ele almaktadır:

\begin{abstract}
Dünyanın küçülerek yoğunlaşması, iletişim ve bilişim teknolojisindeki gelişmelerin, haberleşme ve ulaşımı daha kolay, daha hızlı ve daha ucuz hale getirmesinin ve böylelikle karşılıklı bağımlılığın artmasının sonucudur. David Harvey’in "zamanmekan sıkışması” olarak da tanımladığı bu durum, dünyanın 'tek bir mekân' (one place) olarak küçülmesini, yani M. McLuhan'ın tabiriyle dünyanın "küresel köye" dönüşmesini hızlandırmıştır. Böylece, bilgiyi toparlama, değerlendirme, kullanma ve üretime uygulama daha hızlı ve daha verimli hale gelirken, toplumsal yapıyı etkileyen yönetim, üretim, tüketim ve dağıtım alanlarında köklü değişim ve dönüşümler yaşanmıştır (Çoştu, 2005, s. 97).
\end{abstract}

Çoştu'nun da vurguladığı bu köklü değişim ve dönüşümler ise en çok ulus devletleri etkilemiştir. Chomsky'nin de dediği gibi ulus devletlerin yerine geçen bu çok uluslu şirketler deyim yerinde ise 'yeni köyün yeni muhtarları' haline gelmişlerdir. Yeni düzenin, kaybedenleri olarak görülen devletlerin varlık nedenleri ve işlevleri sorgulanır hale gelmiş ve Hobbes'un (2019) Leviathan'1 yani insanların biricik kutsalı ve uğruna öldüğü devlet, hedef tahtasına oturtulmuştur. Jürgen Habermas (2017), bu konuya daha Chomsky gibi yaklaşır. Habermas'a göre kapitalizm, ulus-devletleri doğurmuş ve küreselleşme ile birlikte yeni dünya düzeninin yeni kapitalizmi de ulus-devletleri ve ulus kültürü aşındırmaya başlamıştır. (Habermas, 2017, s. 32-35).

Dünyanın son otuz yılda geçirdiği bu "ultra-hızlı küreselleşme" sürecini bir çırpıda anlatmak elbette kolay değildir. Ancak bu tartışma sonunda akılda kalanın "Ulus-devletlerin geleceği ne olacak?" sorusunun olduğu kesindir. Küreselleşmenin ulus devletin sonunu getirdiği iddia edilirken bugüne kadar birçok dirençle karşılaştığı da gerçektir. 1997'de Asya' da başlayan ekonomik kriz, Rusya'ya sıçrayarak önce gelişmekte olan ülke ekonomilerini sonra da bütün dünya finans piyasalarını derinden etkilemiş ve dünyadaki küresel finansal piyasaları tedirgin etmiştir. Yeniden toparlayan finansal piyasaların 2008'deki küresel kriz ile birlikte yeniden sarsıldığı görülmüştür. 2008 krizinin artçı etkilerinin özellikle Yunanistan'1 'iflas' noktasına getirdiği bilinmektedir (Evlimoğlu ve Yenipazarlı, 2015, s. 96-103). Bütün bu yaşanan krizlerde çözümü hep bir şekilde ulus-devletlerin sunması ise "Ulus-devlet hala biricik garantimiz mi?" sorusunun yeniden sorulmasına neden olmuştur. Her kriz sonrası yeniden unutulan ulus-devletlerin önemi ise bugün yeniden gündeme gelmiştir. 2019 y1lı sonunda Çin'den başlayarak Dünya'ya yayılan salgın epidemi halini almış ve 2020 yılının ilk beş ayına damga vurmuştur. Sosyal, ekonomik ve siyasi açıdan bütün dünyayı daha önce görülmemiş bir krize sokan bu yeni COVID-19 (yeni tip Korona Virüs) durumu 'yeni düzen’ tartışmalarını yeniden başlatmıştır. Artık bütün dünyanın tek bir gündemi var: COVID-19. Bu süreçte virüsün yayılmadığ 1 ve neredeyse can almadığ 1 ülke kalmamış gibidir. Artık bütün gazetelerin manşetleri, köşe yazılarının ana konusu, televizyon programlarının tek gündemi bu virüsten ibaret görünmektedir. İnsanlar elini nasıl yıkamalı, kendimizi nasıl korumalıyız gibi soruların cevaplarını dünya öğrendi. Ancak akıllarda tek bir soru var: "Bundan sonra dünya düzeni ne olacak?".

'COVID-19 sonrası dünya düzeni', günümüz dünyasının en popüler tartışması haline geldi. Siyasetçiler, ekonomistler, sosyologlar ve sokaktaki insanın başka bir gündemi yok ve hepsi de bundan sonra ne olacağını tartışıyor. "Bundan sonrası hiçbir şey eskisi gibi olmayacak" en popüler söylem. Ancak bundan sonrasının ne olacağı oldukça tartışmalı. Bazı yazarlar COVID-19 ile birlikte küresel piyasaların eskisi gibi olmayacağını söylerken, kimi yazarlar da insanların tüm alışkanlıklarının değişeceğini söylüyor. Ancak herkesin hemfikir olduğu konu sokaktaki insanın asıl meselesinin 'toplumsal sözleşme' ile yetki verdiği devletinin ona ne sağlayacağı. COVID-19 sürecinde ulus-devletlerin aslında aşınmadığı ve gerçek kriz anlarında ilk akla gelen aktör olduğu görülmektedir. Dünyayı bu hale getirenin insan olduğunu düşünürsek, insanlığın da sözleşme ile yetki devri yaptığı devletten çözüm beklemesi akla en çok yatan çözüm olarak görülebilir. İrlandalı iktisat yazarı ve gazeteci David Mc Williams, 
Guardian Gazetesi'ne Yunanistan eski maliye bakanı Yanis Varufakis ile birlikte verdiği bir demeçte bu sürece ilişkin şunları söylemektedir:

“Sanırım kapitalizmin bu benzeri kriz sürecinde 'askıya alındığını' söylemek yanlış olmaz. Artık bundan önceki duruma geri dönmeyeceğiz. Devlet geri döndü ve seçmenler bu yaşananları unutmayacak. Nereye gittiğimizi bilmiyorum ama geriye dönmeyeceğimiz kesin.” (BBC, 2020).

Mc Williams'ın dediği gibi sadece kapitalizm değil BM ve AB gibi devasa uluslararası yapılar da bu süreçte sorgulanmış ve uluslararası yapıdan daha çok merkezi devlet sistemlerinin bu krizde daha etkin davranabildiği görülebilmiştir. Bu durum da devletin ekonomide ne ölçüde etkin olması gerektiği tartışmasını ortaya çıkarmaktadır. Hiç kuşkusuz ki bu durum bundan sonraki süreçte daha çok tartışılacaktır.

\title{
Karikatür ve Önemi
}

Karikatür tarihi, mağara resimlerine kadar yani paleolitik, mezolitik ve neolitik dönemlere kadar dayanmaktadır (Topuz, 1997, s. 16). Karikatürün ve çizimin tarihi insanlık tarihi ile eş olsa da bir iletişim aracı olarak değerlendirebileceğimiz karikatür, 19.Yüzyıl'dan bu yana insanlara modern dünyanın bir resimsel parodisini sunmaktadır. Bugün ise karikatürler genellikle gazetelerde ve dergilerde günlük hayatın içinden toplumsal, siyasi ve ekonomik mesajlar vermek için kullanılır. 20. Yüzyıla giriş ile birlikte karikatür sanatına olan ilgi artmış ve The New Yorker dergisi ile kazanılan ivme tüm dünyaya yayılmıştır (Matzo ve Miller, 2009, s. 489-490). 1922'de Pulitzer ödüllerine karikatürün eklenmesi ve 1942 'den sonra Profesyonel Gazeteciler Cemiyeti (SPJ)'in de her yıl düzenli olarak karikatür ödülleri vermesi ile karikatür iletişim araçları içinde saygın bir yere oturmuştur. Levent Cantek ve Levent Gönenç (2017), karikatürü ve işlevini şu şekilde yorumlar:

\begin{abstract}
Karikatür bir iletişim aracıdır. Karikatürün bu niteliği, bu sanat alanının unsur, işlev ve etkilerini iletişim kuramları yardımıyla açıklamamıza imkân verir. İletişim, en basit biçimde, bir benzetme yardımıyla şöyle tanımlanabilir: 'Gönderici' (sender), bir hedefe atış yapan okçu gibi, vermek istediği 'mesaj' 1 (message), hedef olarak seçtiği 'alıcı'ya (receiver) gönderir; göndericinin, yani karikatürcünün mesajını gönderirken, bu mesajın alıcıya (yani okuyucuya) ulaşırken, bir başka ifadeyle, okuyucu tarafından anlaşılır, beğenilir, takdir edilirse okçu hedefini 'on ikiden' vurmuş, yani iletişim faaliyeti başarıya ulaşmış olur (Cantek ve Levent, 2017, s. 37).
\end{abstract}

Çizen ve o karikatür üzerine düşündüren karikatürist, takipçisine ve topluma mesajını iletmek ister. Bunu yaparken de alanı kısıtlı olan karikatürist en direkt anlatımı en anlaşılır biçimde çizgileri ile yapar. Özellikle gazete ve dergilerin ektisini arttırması ile karikatürün dünya çapındaki etkisi artmış ve eğlenceden çıkıp etkili bir anlatım biçimi ile insanların büyük ilgisini çekmiştir. Abartılı çizimler ile başlayan karikatür sanatı bugünün dünyasında bambaşka bir konuma gelmiştir. Çizimlere eklenen tek cümlelik yorumlar, konuşma balonları karikatürün gücünü arttırmış ve karikatürlerin başlı başına bir manifestoya dönüşmesine olanak tanımıştır. Mehmet Kaya ve Meltem Acarlı (2018) bu durumu şu şekilde anlatırlar:

Karikatür sanatının ilk dönemlerinde tanınmış kişilerin portreleri abartılarak çizilmiştir. Bu nedenle karikatürün "anlam yüklü portre" olduğunu söyleyenler de bulunmaktadır. Ardından gelen süreç içerisinde karikatürlere eşlik eden yazılarda kişi ve olaylar altyazılar eşliğinde verilmiştir. Bu dönemde fıkralar karikatürsel çizgilerle süslenmiştir. Karikatürlerde insan formları deforme edilmiş, abartılarak veya olduğundan daha küçük çizilmiş, herhangi bir canlının vücut veya gövdesinin bir bölümü insana eklemlenmiş olabilir. Söz oyunları yapılarak da komik öğe oluşturmak mümkündür. Başka bir deyişle, karikatür sanatı her türlü olay, olgu, kişi veya nesneyi kendine konu edinebilir. Böylece yaşamın her evresi mizahi bir şekilde ele alınarak toplumu etkileyen her türlü olayın karikatürlerde yeniden üretilerek gündeme getirilmesi sağlanır. Düz bir metinin sayfalarca anlatacağı birçok konu karikatürler aracılığıyla gösterildiğinde etkisi metinden çok daha büyük olduğu yadsınmaz bir gerçektir. (Kaya ve Acarlı, 2018, s. 128). 
Kaya ve Acarlı'nın da belirttiği gibi karikatürün asıl gücü sayfalarca anlatılabilecek bir konuyu yazılı metinden daha güçlü bir şekilde ifade edebilmesidir. Bu açıdan karikatüristler büyük bir muhalefet gücünün öznesi olabiliyorken bazen de büyük krizlerin baş aktörleri olabilmektedir. 2015 yılında yaşanan Charlie Hebdo saldırısı ile karikatürün sınırının ne olması gerektiği tartışılmaya başlamıştır (Çakaş, 2019: s. 76). Çünkü karikatüristin verdiği mesajı selamlayanlar kadar olumsuz karşılayan kitleler de bulunmaktadır. Ancak, bu dahi karikatürün etki gücünü göstermektedir. Karikatürün belki de en önemli özelliği kendi dönemine $1 s ̧ 1 k$ tutması ve gelecek nesillere o dönemki tartışmaları tüm çıplaklığı ile aktarabilmesidir. Karikatürist sadece olayı aktarmaz, aynı çizgiler içerisinde döneminin modasını, siyasal, ekonomik ve sosyal durumunu da aktarır. Karikatürü okuyan herkes, karikatürün yayınlandığı dönem hakkında bir fikir sahibi olabilir. Karikatürün gücü hafife alınsa da en net darbeyi vurma gücüne sahip olduğu için her dönem etkili olmuştur. Örneğin Abidin Dino, "Karikatürün içtimai silah olarak yazıdan, şiirden ve resimden daha kuvvetli olduğu bir gerçektir. Büyük halk kitlelerine hitap etmek isteyenler için karikatürün en kısa yol olduğu bilinmektedir." demekte ve karikatürün bu gücünü vurgulamaktadır (Özocak, 2011, s. 264).

Karikatür aynı zamanda sokaktaki insanın kendi dönemine dair söylemek istediklerini yansıtan bir araçtır. Bu açıdan karikatürün her daim muhalif bir bakış açısına sahip olduğu söylenebilir. Zira karikatür, hiciv eder, yerer, güldürür ve düşündürür. Karikatürün bu özelliğini Gürkan Özocak şu şekilde açıklar:

Karikatür ve mizah da, ifade özgürlüğünün bir tezahürü olarak, toplumların tarihinde oldukça önemli bir yere sahiptir. Özellikle siyaset ile olan ilişkisinde, karikatürün siyasi iktidarları hicvetme aracı olarak, ellerinde bulundurdukları iktidarı kendilerine çıkar sağlayacak biçimde, keyfi ve geniş halk kitlelerinin aleyhine kullandıklarında, iktidarlar bakımından bir nevi 'kamuoyu denetimi' işlevi gördüğü söylenebilir. (Özocak, 2011, s. 291).

Küreselleşmenin etkisi ile birlikte sermayenin iktidar olması ile dördüncü kuvvet olarak basın, yasama, yürütme ve yargı üçlüsünü denetleme görevini yerine getiremez olmuş ve medya uluslararası sermayelerin veyahut bizzat hükümetlerle iş yapan iş adamların eline geçmiştir. $\mathrm{Bu}$ açıdan da Özocak'ın da vurguladığı gibi 'kamuoyu denetimi' karikatüristlere ve çizdikleri karikatürlere kalmıştır. Özellikle basının 'yazamadığı' ve 'göremediği' olayları nüktedan bir şekilde cesurca ele alan karikatüristler tarih boyunca birçok iktidarın ve sermayedarın hedefi olmuşlardır. Ancak bugün gelinen noktada geçmiş hafızayı okumada karikatürlerin en iyi kaynaklardan biri olduğu gerçektir. Onun için de 'dünya düzeni' tartışmalarının en iyi ve en net okunabileceği kaynakların başında karikatürler gelmektedir.

\section{COVID-19 Düzenini Karikatürler Üzerinden Okumak}

2019 yılı biterken kimse 2020 yılının tek bir olayla anılacağını elbette düşünemezdi. Çin'den başlayıp tüm dünyaya yayılan yeni bir virüs, tarihte eşi benzeri görülmemiş bir yıkıma sebebiyet vermiş ve dünya üzerinde etkilenmedik bir tek nokta bırakmamıştır. Yeni tip korona virüs yani Dünya Sağlı Örgütü'nün deyimi ile COVID-19, siyasetten, ekonomiye, iletişimden, psikolojiye neredeyse hayatın tüm alanını derinden etkilemektedir. Mayıs 2020 sonu itibari ile COVID-19, 200'den fazla ülkede tespit edilmiş, dünya genelinde toplamda 7 milyona yakın kişiye bulaşmış ve 400.000'e yakın can kaybına neden olmuştur (Worldometers, 2020). 2020 yılının ana gündem maddesi haline gelen bu yeni pandemi durumu en çok sokaktaki insanı etkilemiştir. ABD, Fransa, İtalya ve İngiltere gibi gelişmiş ülkelerdeki sağlık altyapısının yetersizliği tartışma konusu olmuş ve yine milyonlarca insan bu süreçte karantina sebebi ile işsiz kalmak zorunda kalmıştır (NTV, 2020). Dünyayı bu kadar etkileyen bu durum hiç kuşkusuz ki karikatür dünyasını da derinden etkilemiştir. Özellikle sokaktaki insanı ve sokaktaki insanı resmeden karikatürlerin ilerleyen yıllarda bu dönemi anlatan en iyi belgelerin arasına gireceği bir gerçektir. Çalışmanın evrenini COVID-19 süresince yayınlanan tüm karikatürler oluşturmaktadır. Evrenin tamamına ulaşmak zaman ve maddi açıdan mümkün 
olmadığından çalışmanın örneklemi, olasılıklı olmayan amaçlı örneklem yöntemi kullanılarak dünyada COVID-19 ile ilgili bağımsız karikatüristlerce yayınlanmış olan karikatürler olarak belirlenmiştir. Söz konusu örneklem oluşturulurken küreselliğin yansitılabilmesi ve analizlerin çok boyutlu olarak yapılabilmesi için farklı ülkelerden bağımsız karikatürler seçilmiştir. Bu açıdan ilk olarak, karikatüristlerin COVID-19 ekonomisine bakış açısı incelenmiş daha sonra pandeminin siyaset ve topluma nasıl yansıdığı karikatürler üzerinden yorumlanmıştır.

\section{Karikatürlerde COVID-19 ve Ekonomi}

COVID-19'un dünyaya yaptığı en büyük etki hiç kuşkusuz ki küresel ekonomiyi alt üst etmesidir. 2008'deki küresel ekonomik krizden bu yana toparlanmaya çalışan küresel ekonomi, pandemi süreci ile çok büyük bir darbe almıştır. Özellikle petrol fiyatlarının neredeyse eksilere düşmesi, üretimdeki daralma, dünya borsalarının tepe taklak dip seviyeleri görmesi ve ülkelerin ardı ardına ekonomik kurtarma paketleri açıklamaya başlaması bunun en büyük göstergesidir (Mahar, 2020).

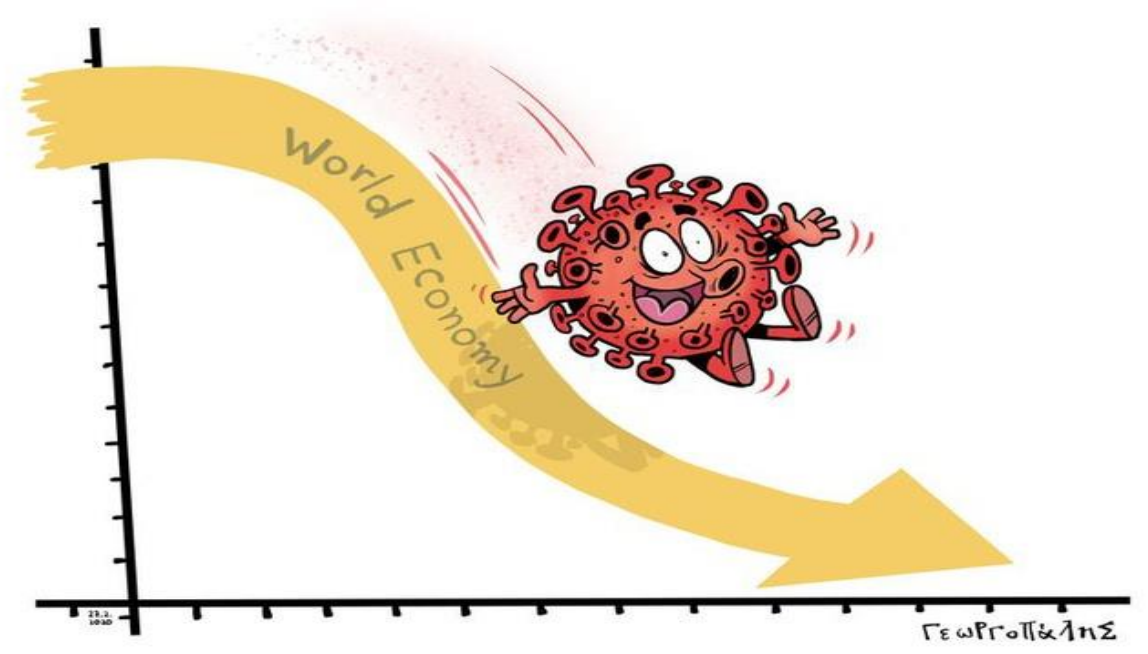

Resim 1: Korona Virüs Dünya Ekonomisi ile Oynuyor (Georgopalis, 2020)

Yukarıdaki karikatür (Resim 1), 2020 yılı yılında Yunan Karikatürist Dimitris Georgopalis tarafından çizilmiştir. Karikatürist, virüsün dünya ekonomisini oldukça basit ve net anlatmıştır. Georgopalis, küresel ekonominin virüs için bir çocuk oyunu haline geldiğini vurgulamak için karikatürdeki ikstisadi grafiği bir kaydırağa, virüsü de bir çocuğa benzetmiştir. 


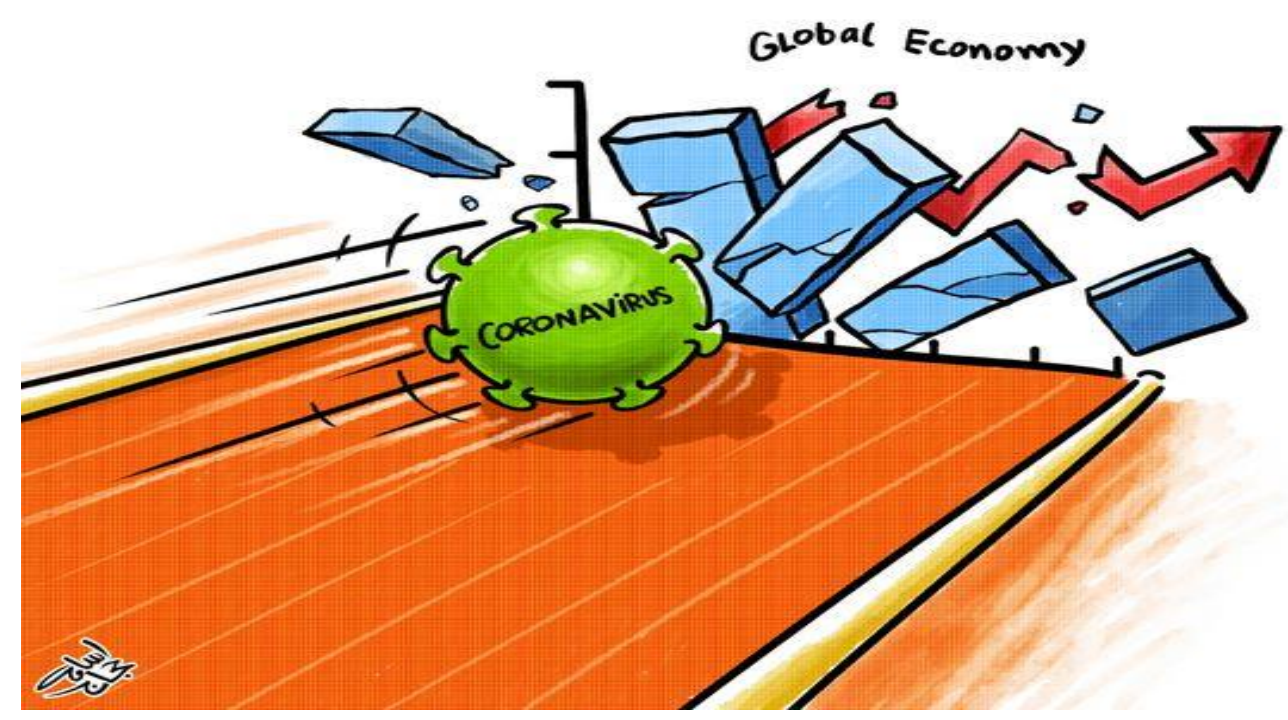

Resim 2: Koronavirüs ve Küresel Ekonomi (Hajjaj, 2020)

COVID-19'un ekonomiye etkisini anlatan bu ikinci karikatür (Resim 2) ise Ürdünlü karikatürist Osoma Hajjaj'a aittir. Hajjaj, virüsü yarış pistindeki bir atlete benzetmiş, virüsün hızını ve pistteki rakipsizliğini çizgilerle anlatmaya çalışmıştır. Yarış sonundaki bitiş çizgisini ise küresel ekonomi grafiği oluşturmakta ve virüs, bitiş çizgisini geçmeden çizgiyi dağıtmayı başarmıştır. Sanatçı, virüsün bugüne kadar küresel ekonomiye en hızlı ve en büyük darbeyi vurduğunu anlatmak istemektedir.

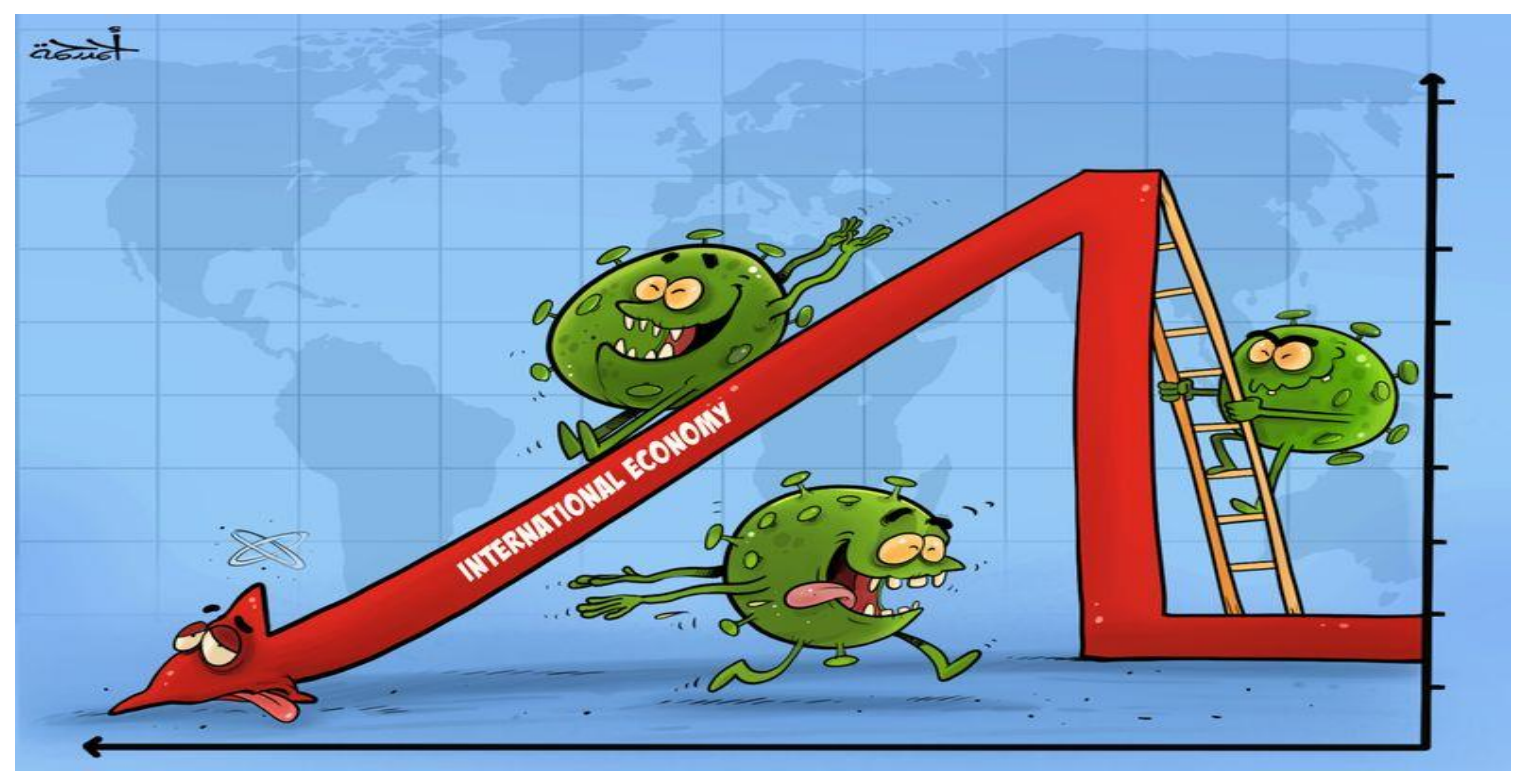

Resim 3: International Economy (Rahma, 2020)

Çalışmada ekonomi ile ilgili inceleyeceğimiz son karikatür ise Türkiye'de yaşayan Arap Karikatürist Ahmad Rahma'ya aittir. Rahma da diğer iki karikatürist gibi 'oyun' temasını kullanmış ve corona virüsün uluslararası ekonomi ile bir oyun gibi oynadığını vurgulamıştır. Burada uluslararası ekonomiyi temsil eden bir finansal grafik, Rahma tarafindan oyun parkındaki bir kaydırağa benzetilmiş ve virüsü temsil eden simgelerin de yorulmadan ve hatta kaydırağı yorarak oynadıkları aktarılmaktadır. Karikatürde yer alan unsurlara göre uluslararası 
ekonomiyi temsil eden kaydırak, başını kaldırmaya takati kalmamış bir halde iken COVID-19 da durmaya niyeti olmayan bir halde resmedilmiştir.

\section{Karikatürlerde COVID-19 ve Siyaset}

COVID-19 pandemisi ekonomi ile birlikte siyaseti de derinden sarsmıştır. Özellikle küreselleşme tartışmalarında aşınacağı iddia edilen ulus devletin pandemi sürecinde yeniden ortaya çıkışı ve liderlerin pandemi ile mücadeleye yönelik söylemleri herkes kadar karikatüristlerin de ilgisini çekmiştir. Pandemi sürecindeki bir diğer tartışma da uluslararası sistemde lider olarak görülen ABD, Çin, İngiltere ve Rusya gibi ülkelerin pandemi ile mücadelede beklenen liderliği sergilemek bir yana kendi içerisindeki sorunlarla mücadele edemediği gerçeğidir (Taylor, 2020). Yine bu süreçte Avrupa Birliği'nin geleceği de tartışmaya açılmış ve birliğin üyelerine pandemi sürecinde yeterli desteği sağlamaktan aciz olduğu iddiaları ortaya atılmıştır (The Guardian, 2020).

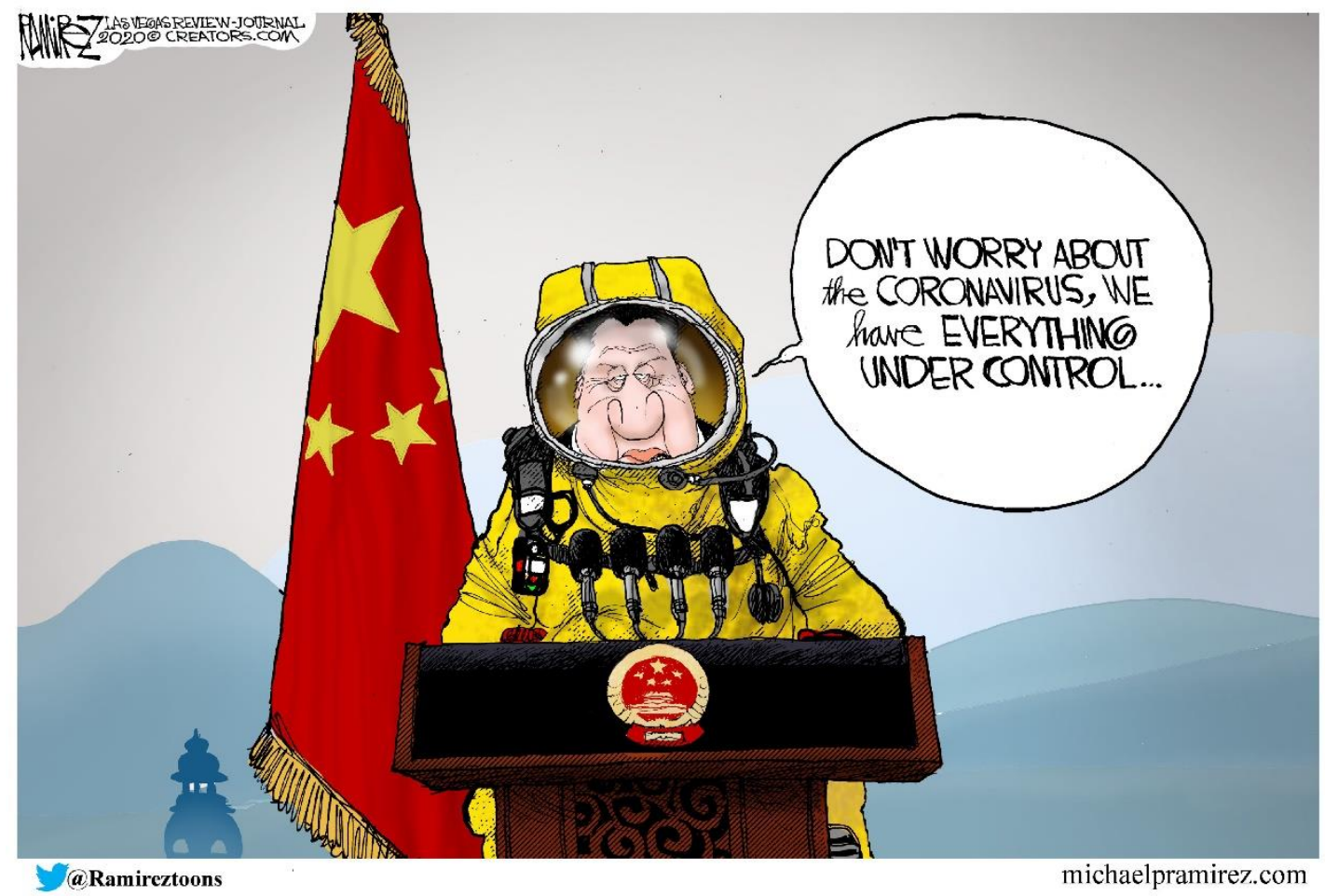

Resim 4: Koronavirüs kontrol altında, bize güvenin (Ramirez, 2020)

Çalışma kapsamında COVID-19'un siyasete etkisi kapsamında incelenecek ilk karikatür (Resim 4), iki kez Pulitzer ödülü kazanan ABD'li karikatürist Michael Ramirez'e ait. Ramirez karikatüründe, virüsün ilk duyulmaya başladığı zaman Çin'in yapmış olduğu "her şey kontrol altında" açıklamasını resmetmiştir. Karikatürde, her şeyi kontrol altında tuttuklarını söyleyen ve insanlara endişelenmemelerini öğütleyen Çin Devlet Başkanı Xi Jinping resmedilmiştir. Ramirez'in karikatürü, Jinping'in açıklama esnasında giydiği ve Taykonot kıyafetine benzetilen koruyucu kıyafet ile basın açıklamasındaki söylem arasındaki çelişkiye dikkat etmemizi istediği şeklinde yorumlanabilmektedir. 


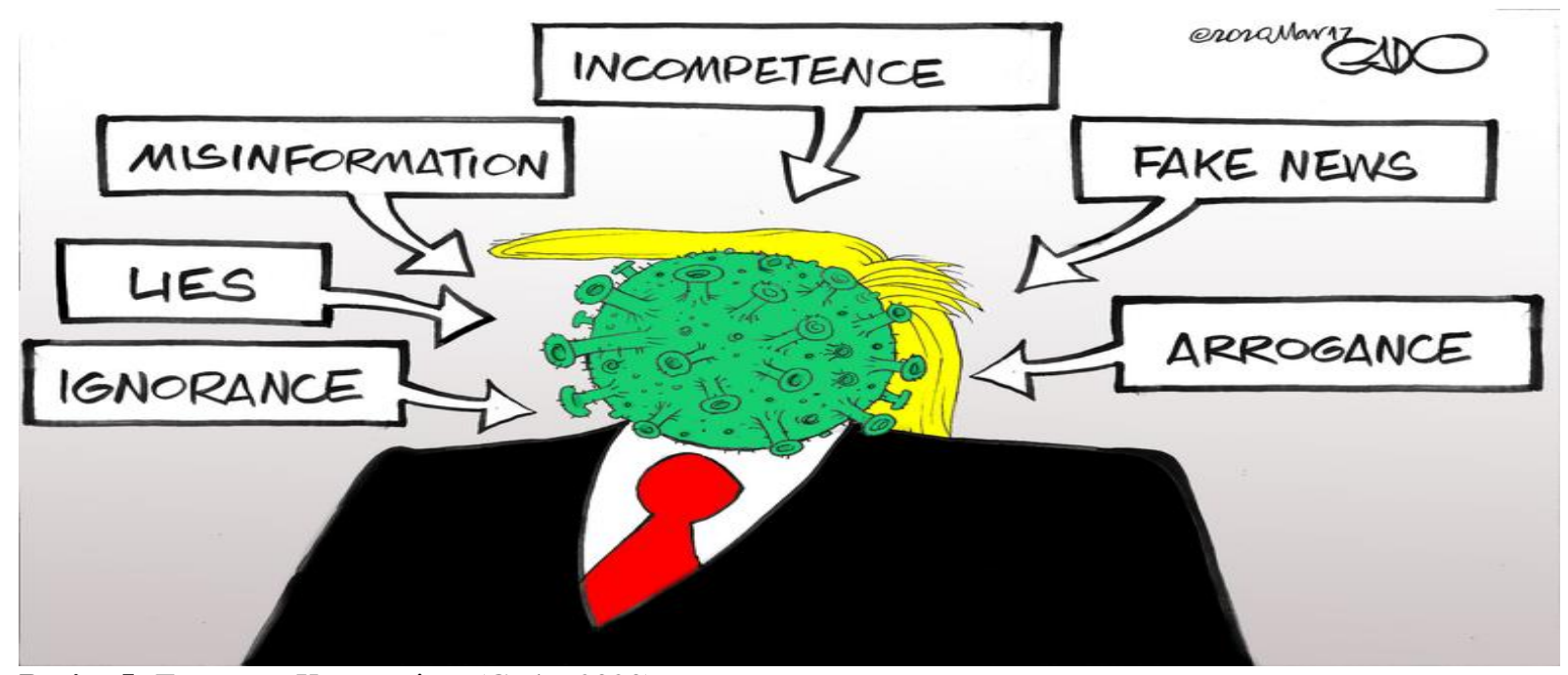

Resim 5: Trump ve Koronavirüs (Gado, 2020)

Çalışmada siyaset teması ile incelenen ikinci karikatür ise Kenya'dan kalem adı Gado ile ünlü olan Godfrey Mwampembwa'ya aittir. Gado, karikatüründe ABD Başkanı Trump'ın yüzü yerine koronavirüs imgesini yerleştirmiş ve Trump' nn pandemiye ilişkin tutumu sebebi ile Trump'a dair yakıştırılan sıfatları karikatüründe kullanmıştır. Bu sözcükler sırası ile şunlardır: beceriksizlik, yanlış bilgi, yalan, cehalet, yalan haber ve kibir. Trump'ın pandemi sürecinde yaptığı neredeyse tüm açıklamaların skandallara sebep olduğu hatırlanacak olursa sanatçının anlatmak istediği daha net anlaşılabilecektir. Sanatçının, bu karikatürü, okuyucuya hem kendi Trump algısını yansıtmak istediği hem de Trump'ın da en az koronavirüs kadar tehlikeli olduğunu belirtmek istediği şeklinde yorumlanabilmektedir.

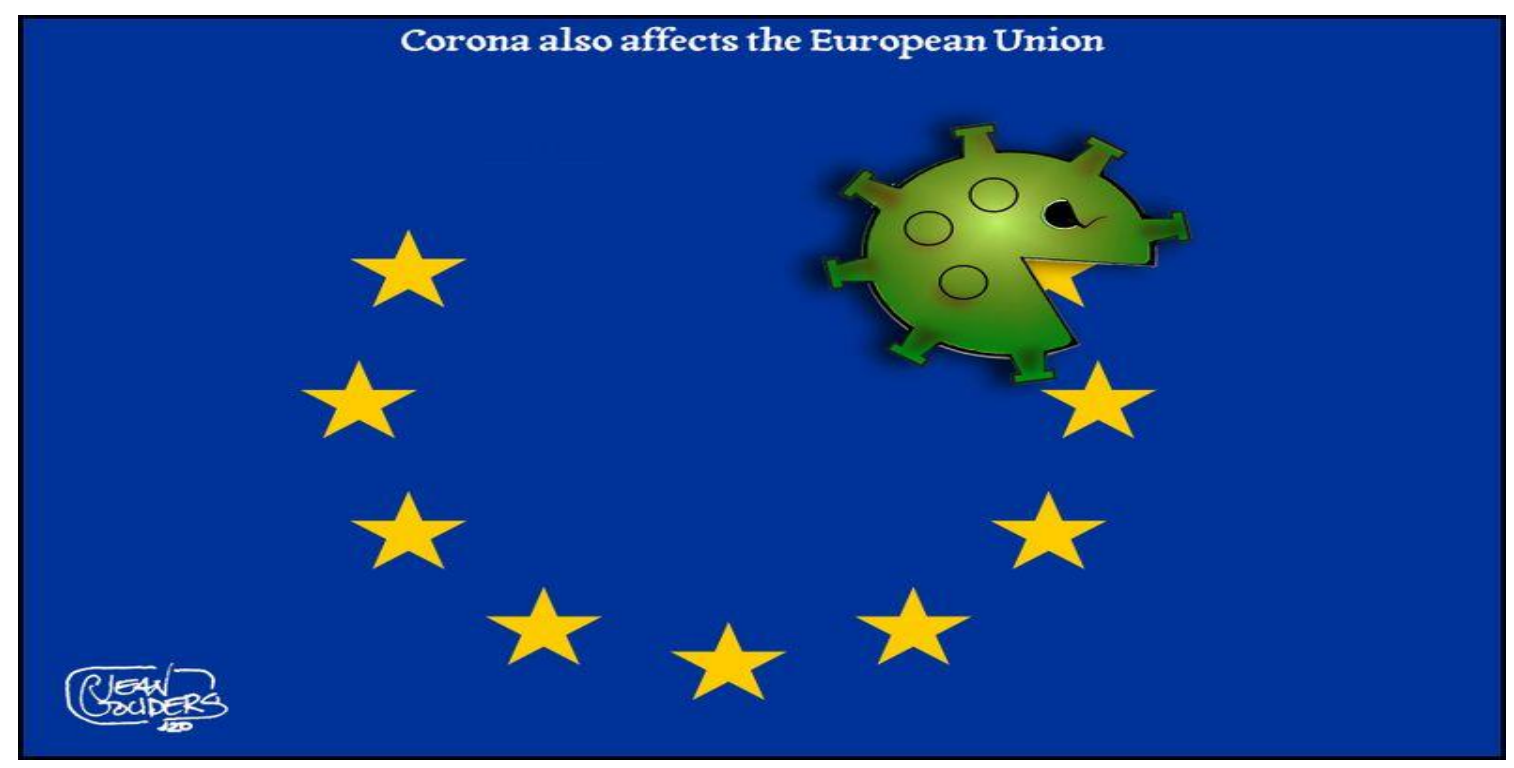

Resim 6: Korona, aynı zamanda Avrupa Birliği’ni de etkiliyor. (Gouders, 2020)

Bu kapsamda incelenecek son karikatür (Resim 6) ise Hollandalı karikatürist Jean Gouders'e aittir. Gouders, “Korona, aynı zamanda Avrupa Birliği’ni de etkiliyor" başlığını kullandığı karikatüründe sadece iki simge yani $A B$ bayrağı ve korona virüs simgesini kullanarak vermek istediği mesajı net olarak okuyucusuna iletmektedir. Sanatçı, pandemi sürecinde birliğin içinde bulunduğu çaresiz durumu ve birliğin geleceği ile ilgili tartışmaları yansıtmak istediği karikatüründe korono virüsü ünlü video oyunundaki 'pac-man' simgesine dönüştürmüştür. Karikatürde pac-man'a dönüşen korona virüs imgesi, on iki yıldızdan oluşan $\mathrm{AB}$ bayrağındaki dört yıldızı yemiş durumdadır. Gouders'in bu karikatürü, COVID-19 
pandemisinin "AB rüyasını yiyip bitirmek üzere” olduğunu okuyucularına aktarmak istediği şeklinde yorumlanabilmektedir.

\section{Karikatürlere COVID-19 ve Toplum}

Korona virüsün en çok etkilediği ve en az sesini duyduğumuz kesim ise hiç kuşkusuz ki sokaktaki insan yani toplumdur. Yüzbinlerce insanın hayatını kaybettiği ve milyonlarca insanın ekonomik bir yoklukla mücadele etmek durumunda kaldığ bu süreçte, siyasetçiler halka karşı olumlu bir hava vermek isteseler de gerçek tahmin edilenden daha kötüdür. Ancak, bu gerçeğin medyaya yansıması ve siyasetçilerin söyleminde yer bulması ise oldukça sınırlıdır. İnsanlara siyasiler tarafindan evde kalmaları, maske takmaları ve ellerini en az yirmi saniye yıkamaları ögütlenmiş ancak bu sürecin ekonomik, sosyal ve psikolojik etkileri ile ilgili bir şey söylenmemiştir. Tam da bu noktada, sokaktaki insanın yani toplumun durumunu en kısa ve öz bir biçimde aktaran karikatüristler devreye girmektedir.

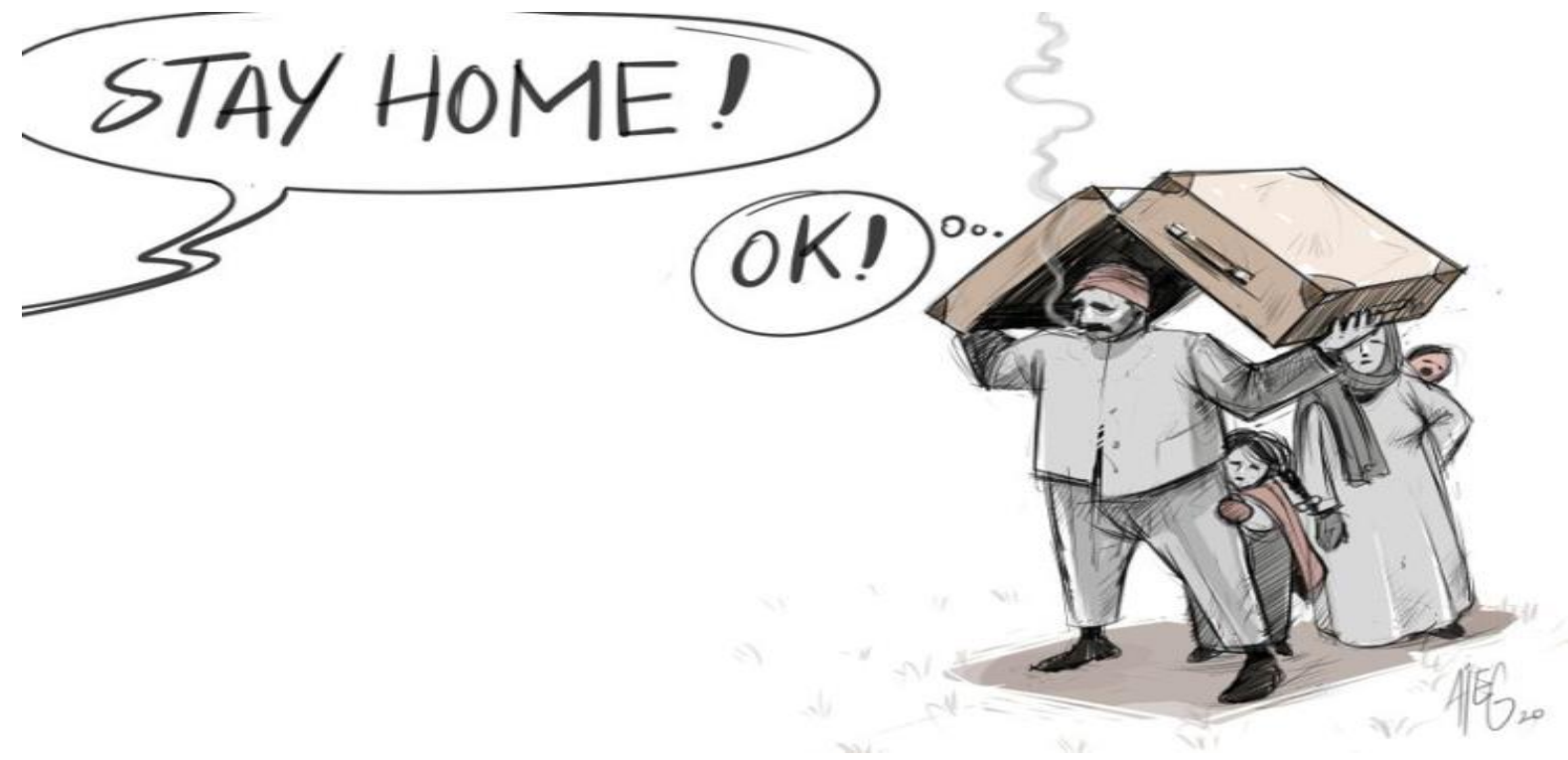

Resim 7: Stay Home (Ajeg, 2020)

Çalışma kapsamında toplum teması altında analiz edilen ilk karikatür (Resim 7), Faslı karikatürist Mohamed Ajeg'e aittir. Ajeg, karikatürü ile siyasetçilerin 'evde kal' çağrılarına beklenmedik bir şekilde cevap vererek, takipçilerine bir anlamda ters köşe yapmaktadır. Zira COVID-19 gündemine kadar dünyanın en önemli gündem maddelerinden biri de mülteci sorunu idi. Ajeg, tam da bu noktada devreye girerek mültecilerin sorununu hatırlatmaktadır. Karikatürist, mesajını iletebilmek için önce yüksek perdeden siyasilerin ve uzmanların 'evde kal' çağrısına atıfla kalacak yerleri olmayan yorgun, üzgün ve korku dolu bir mülteci ailesi resmetmektedir. Ailenin, tek şahsi mülkiyetleri olarak ellerinde kalan bavulu bir ev çatısı şeklinde çizilerek, mültecilerin kalabilecekleri bir yerlerinin olmadığının vurgulanmak istendiği şeklinde yorumlanabilmektedir. 


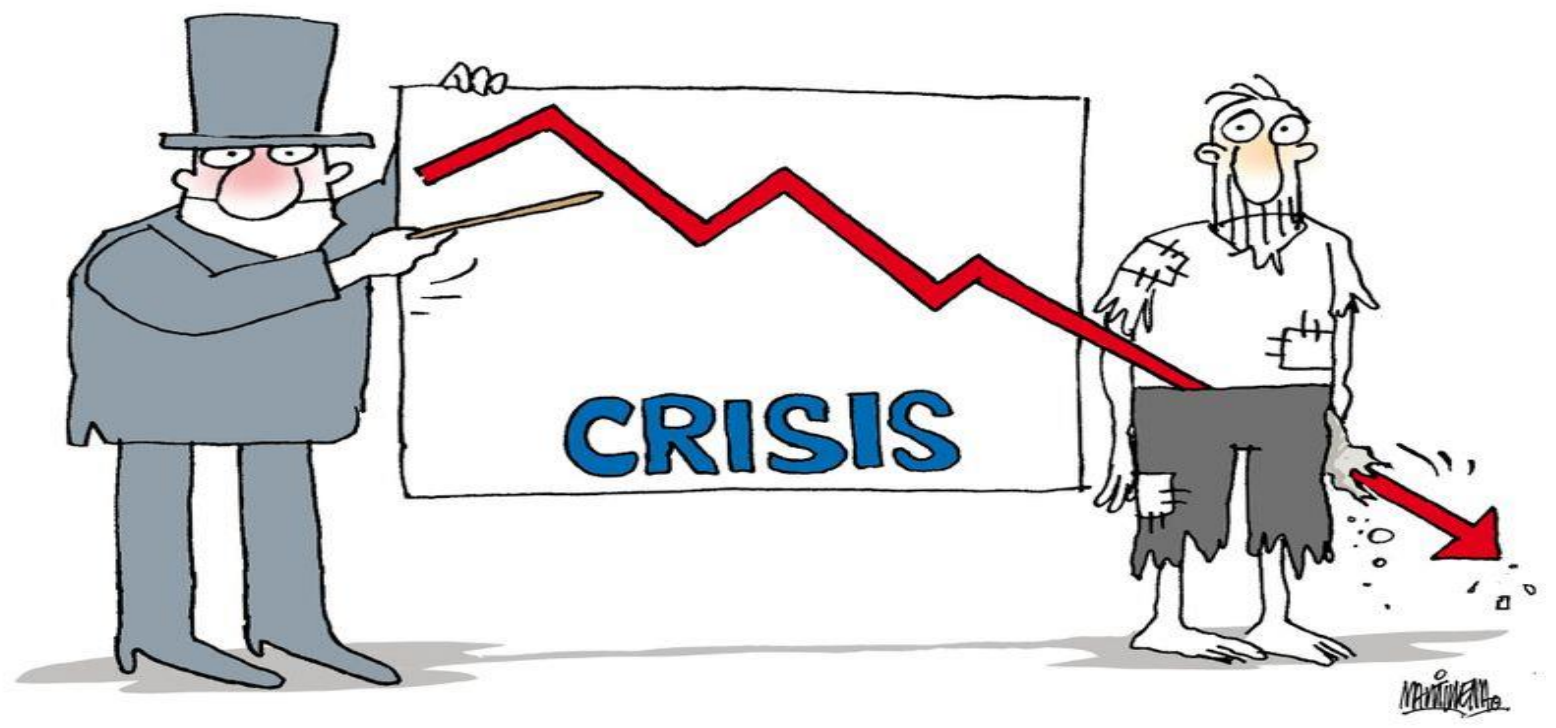

Resim 8: Zengin ve Yoksulun Krizi (Martinera, 2020)

Pandemi sürecinin ekonomik etkilerinin toplumdan bağımsız olarak değerlendirilmesi mümkün değildir. Bu bakımdan çalışma kapsamında toplum teması ile analiz edilen bu karikatür (Resim 8), Kübalı sanatçı Alfredo Martinera'ya aittir. Sanatçı, karikatüründe pandemi sebepli ekonomik krizin zenginden çok yoksulu etkileyeceğini vurgulamak istemektedir. Karikatürist, mesajını kırmızı burunlu şapkalı zengin ve pespaye giyimli solgun suratlı bir yoksul imgelemi üzerinden vermektedir. Karikatür, "zengin krizi anlatır, yoksul ise gerçek manada hisseder" şeklinde yorumlanabilmektedir. Martinera, yoksulun krizi hissetmesini vurgulamak için düşen ekonomik göstergeyi yoksulun içinden geçirmektedir.

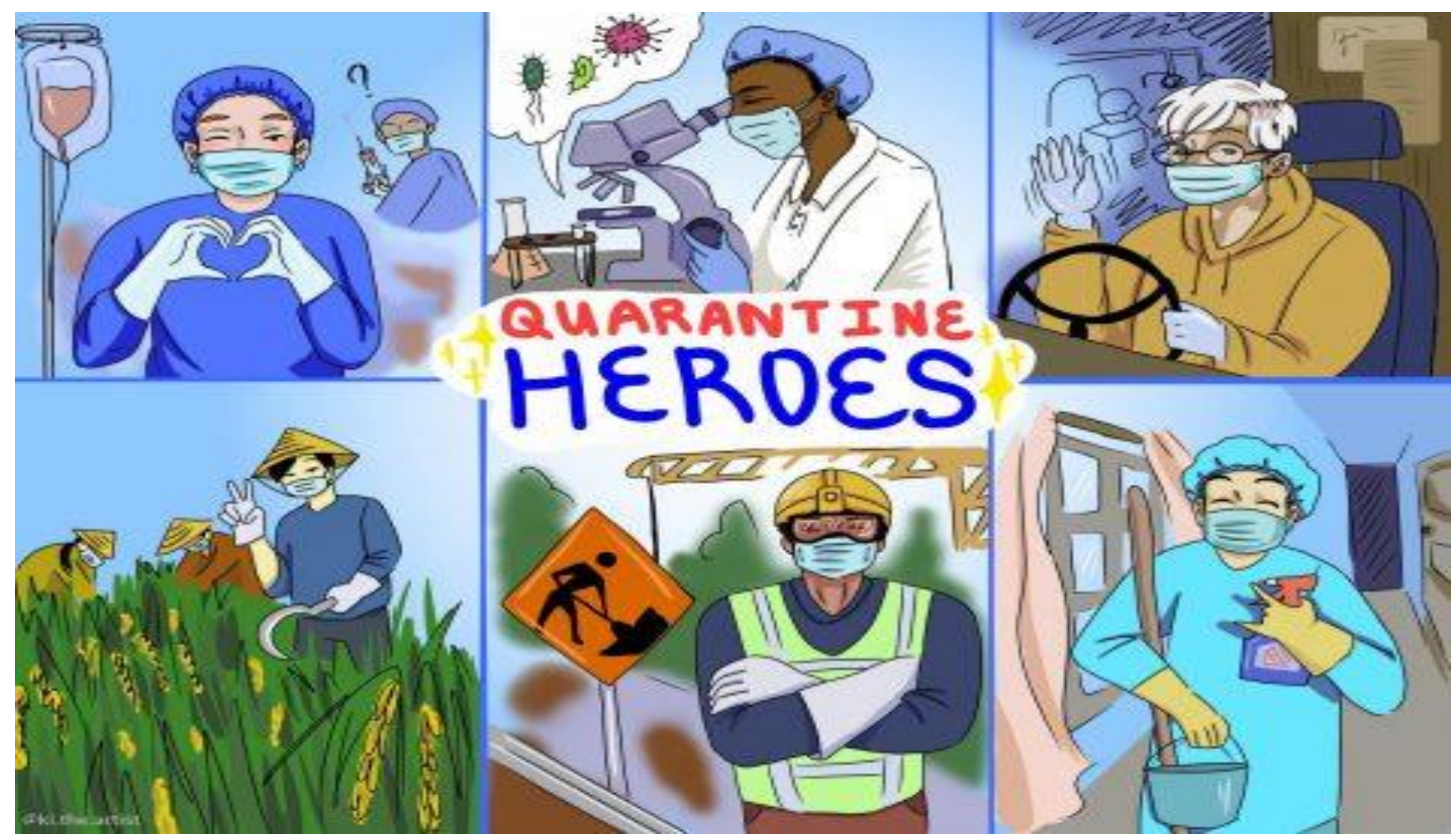

Resim 9: Karantina Kahramanları (Lapshina, 2020)

Çalışma kapsamında toplum teması ile analiz edilen on karikatür (Resim 9) ise ABD'de bir lise öğrencisi olan Ksenia Lapshina'ya ait. 'Karantina Kahramanları' ismini taşıyan karikatürde Lapshina, pandemiye karşı savaşta gerçek mücadeleyi verenleri yansıtmaya çalışmıştır. Karikatürde dikkat çeken sadece meslek grupları değil, aynı zamanda farklı etnik kimliklerde resmedilen karakterlerdir. Bütün dünyanın 'evde kal' çağrısı ile gönüllü bir tecride 
girdiği dönemde dışarıda kalarak virüs ile karşı karşıya kalan ve bunu hem işleri olarak hem de insanlığa karşı bir görev olarak gören insanları birer kahraman olarak aktaran karikatürde, herhangi bir siyasinin ve ulus devlet imgesinin olmaması dikkat çekicidir.

\section{Sonuc}

COVID-19 pandemisinin küresel dünyanın son 30 yılda yaşadığı tüm krizlerden daha sarsıcı olduğu tartışılmaktadır. Yaşanan krizin ne zaman biteceğine dair kimsenin fikrinin olmaması gelecek ile ilgili spekülasyon senaryolarının ortaya çıkmasına neden olmaktadır. Pandemi ile birlikte korku da hızla artmakta ve ortaya çıkan belirsizlik hem insanları hem de Soğuk Savaş sonrası kusursuz işlediğine inanılan ve önüne çıkan her krizi bir şekilde atlatan küresel sistemi de ürkütmektedir. Küreselleşme ile birlikte aşınacağı ve belki de zamanla ortadan kalkacağı iddia edilen ulus devletler, bu krizle birlikte varlığını kanıtlamaya çalışan tek yapı olarak görünmektedirler. Ulus devletlerin bu krizde ön plana çıkmasının en önemli sebebi uluslararası sistemin pandemi ile birlikte bir belirsizliğe yani kaosa sürüklenmesidir. Zira bugün hala krize karşı, uluslararası bir işbirliği geliştirilebilmiş değildir. Özellikle Avrupa Birliği ile birlikte inşa edilen 'Avrupa Rüyası' kavramının tartışmaya açılması ve birliğin krize karşı 'birlik' olamaması dikkat çekmektedir. COVID-19 pandemisi, bu süreçte hem ulusal hem ulus üstü hem de uluslararası kurumlar için hayati bir sınav niteliği kazanmıştır.

Dünyanın yaşadığı bu süreç, insan ve toplum hayatına dair önemli değişikliklere sebep olmuştur. COVID-19 ile birlikte ilk etapta ortaya çıkan komplo teorileri, virüsün bütün dünyay1 etkisi altına alması ile sona ermiş durumdadır. Yine bu süreçte, insanların popülist siyasetçilere değil bilime kulak vermek istedikleri görülmektedir. Yani gelinen noktada alanında uzman olan insanların söyledikleri, popülist siyasilerin ortaya sürdüğü 'Çin Virüsü', 'sürü bağışıklığı' ve 'havalar ısınınca virüs biter' söylemlerini yenmiştir. Çözüm üretmek yerine günü kurtarmak isteyen siyasilerin pandemi süreci sonrası tartışma konusu olacağı söylenebilecektir. Özellikle, İngiltere'nin pandemiye karşı krizin başında takındığ 1 tutum, Trump'ın her basın toplantısında gazetecilere verdiği absürt cevaplar ve Çin'in krizin ilk günlerinde yaptığ 1 "bir sorun yok, her şey kontrol altında" açıklaması tarihe not olarak düşülecektir. Bu krizin bir diğer sonucu da insan hayatının, siyasi çıkarlardan daha önemli olduğu gerçeğini tüm dünyaya bir kez daha hatırlatmasıdır.

Pandeminin bir diğer etkisi de dünya düzeni tartışmalarına ilişkindir. Soğuk Savaş sonrası 'tek taraflı' olarak inşa edilen küreselleşmenin getireceği 'yeni dünya düzeni' en popüler tartışmalardan birisi olmuştu. Küreselleşme ile dünyanın küçüleceği, savaş riskinin ortadan kalkacağı ve gelişen teknoloji ile insan hayatının kolaylaşacağı söyleniyordu. Ancak aradan geçen otuz yılda, ne insan hayatı tüm insanlık için kolaylaşmıştır ne de savaş riski ortadan kalkmıştır. Belki de tek gerçek olan öngörü dünyanın küçülmesi olmuştur. Zira Çin'den yola çıkan bir virüs çok kısa bir sürede tüm dünya sistemini alt üst etmeyi başarmıştır. Bu durum da küreselleşme ile 'yeni dünya düzensizliği' ve 'küresel risk toplumu' tartışmasını yeniden canlandırmıştır. Zira gelinen süreçte, küreselleşmenin ve etkilerinin insanlığı yüz yüze bıraktığı düzensizlik ve riskler dünya tarafından tartışılmaya başlanmıştır. Bundan sonraki tartışma ise bu düzensizliğin ve riskin nasıl ortadan kaldırılabileceği veya azaltılabileceği üzerine olmalıdır.

İletişim sürecinde kaynaktan iletilen mesajlar alıcının zihinsel sürecinden geçerek algılanmaktadır. Bu süreçte mesajı ve anlamı güçlendirmek için imge, metafor ve metonomi gibi unsurların kullanılması anlamın zenginleştirilmesi ve mesajla doğrudan anlatılanların yanında aslında direkt olarak gösterilmeyenlerin de çağrıştırılmasına olanak tanımaktadır. Karikatürler de kuşkusuz ki gösterdiklerinin yanı sıra aslında direkt olarak gösterilmeyen pek çok hususu da aktarmak istemektedir. Bu zengin anlamlı yapısı karikatürlerin birçok mesajı alıcılara aktarmasına yardımcı olmaktadır. Karikatürlerin pandemi gibi küresel öneme sahip bir süreçte mesaj aktarımı için etkin bir araç olarak kullanıldığı görülmektedir. 
COVID-19 sürecini en kısa ve en net bir şekilde anlatanlar ise hiç kuşkusuz ki karikatüristler olmuştur. $\mathrm{Bu}$ süreçte tüm medya gündemini pandemi oluşturduğu gibi karikatüristlerin de ana gündemini 'COVID-19' oluşturmaktadır. Çalışma için herhangi bir medya sermayedarı bünyesinde çalışmayan ve uluslararası sermayeden bağımsız olarak çizimlerini internette yayınlayan karikatüristlerin çizimleri analiz edilmiştir. 'Ekonomi', 'siyaset' ve 'toplum' temaları kapsamında yapılan incelemede, karikatüristlerin yaşanan sürece eleştirel bir tutumla yaklaştığ görülmektedir. Ekonomi hususunda karikatüristlerin ortak kanısının, küresel sermaye ve finans piyasası olarak insanların zihninde 'devleşen' mevhumun aslında ne kadar zayıf olduğu şeklinde ifade edilebilmektedir. Yine karikatüristlere göre korona virüs, uluslararası ekonomi ile bir oyun gibi oynamakta ve her oyunda ekonomiyi 'alt' etmektedir. Karikatüristlerin pandemi sürecinde siyasete bakış açısı ise yine eleştirel ve iğneleyicidir. Dünya düzeninin bundan sonraki geleceği tartışmasını, AB gibi kurumların 'birlik' fikrinin tartışmalı olduğunu yine okuyucular karikatüristlerin çizimlerinden takip edebilmektedirler. Dünya liderlerinin gerçekleri anlatmadığını ve aslında virüs kadar tehlikeli ve sinsi olduklarını resmeden karikatüristler, yaşanan bütün süreci oldukça basit bir şekilde okuyucularına aktarabilmişlerdir. İncelenen son tema pandeminin topluma etkisinde ise karikatüristlerin sorulamayan veya unutulan soruları sorma cesaretini gösterdikleri görülmektedir. Örneğin, bu süreçte 'evde kal' çağrılarına rağmen kimsenin aklına gelmeyen sokaktaki, sınır kapılarındaki mültecilerin durumu karikatüristler tarafından gündeme getirilmektedir. Yine yaşanan ekonomik krizin, dünya piyasalarını değil ekonomi bültenlerinde 'resesyon', 'daralma' ve 'petrol fiyatları' spotları arkasında unutulan yoksulu daha derinden etkileyeceği gerçeği en net bir şekilde karikatüristler tarafından ifade edilmektedir. Son olarak karikatüristler, yaşanan süreçte gerçek kahramanların tarlada üretimi devam ettiren, hastanede hastalara bakan ve evde kalanlara hizmet etmek için tehlikeye karşı çalışmaya devam eden her milletten ve her inançtan 'sıradan süper insanlar' olduğunu hatırlatmakta ve bizleri kutsallaştırdığımız popülist siyasileri ve medyadaki işbirlikçilerini sorgulamaya davet etmektedirler.

\section{Kaynakça}

Ajeg, M. (2020). Stay home. Erişim tarihi: 30. 04.2020 https://blog.cartoonmovement.com/2020/03/the-coronavirus-crisis-in-10cartoons.html.

Akova, S. (2016). Televizyon reklamlarında kullanılan animasyon reklam filmlerinin hatırlanma düzeyleri: "Sağolasın İzocam” reklam filmi örneklemi”. Uluslararast Sosyal Araştırmalar Dergisi, 9(43), 1590-1601.

Bauman, Z. (1998). Küreselleşme: toplumsal sonuçları (7. Baskı.). (A. Yılmaz, Çev.) İstanbul: Ayrintı.(1998).

BBC. (2020, Mayıs 6). Koronavirüs ve kapitalizm: İktisatçılar krizin sistemi nasıl değiştirebileceğini tartışıyor. Erişim tarihi: 07. 05. 2020. BBC Türkçe: https://www.bbc.com/turkce/haberler-dunya-52564144.

Beck, U. (2013). Siyasalliğın icadı (3. Bask1). (N. Ülner, Çev.) İstanbul: İletişim.

Cantek, L. ve Levent, G. (2017). Muhalefet defteri: Türkiye'de mizah dergileri ve karikatür. İstanbul: Yapı Kredi Yayınları.

Chomsky, N. (2003). Dünya düzeni: eskisi yenisi (2. Baskı.). (A. Çakıroğlu, ve T. Birkan, Çev.) İstanbul: Metis Kitap (1994).

Çakaş, C. Ö. (2019). Avrupa'da Müslüman kimliği üzerinden yükselen krizler: karikatür ve başörtüsü krizleri. Bingöl Üniversitesi İktisadi ve İdari Bilimler Fakültesi Dergisi, 3(2), 73-92. 
Çoştu, Y. (2005). Küreselleşme üzerine bazı düşünceler. Gazi Üniversitesi Çorum Illahiyat Fakültesi Dergisi, IV(7-8), 95-104.

Evlimoğlu, U., \& Yenipazarlı, A. (2015). Dünyada yaşanan son ekonomik krizlerin ortak paydası: yayılma etkisi ve belirleyicileri üzerine bir değerlendirme. Kaü İbf Dergisi, 6(10), 91-112.

Fukuyama, F. (1989). The end of history. The National Interest, Summer (16), 3-18.

Gado. (2020). Trump and Coronavirus. Kenya. Erişim tarihi: 27. 04.2020. http://gadocartoons.com/trump-and-corona-virus/.

Georgopalis, D. (2020). Coronavirus is playing with the world economy. Yunanistan. Erişim tarihi: 29. 04. 2020. https://www.irancartoon.com/site/daily/political/coronavirus-isplaying-with-the-world-economy-dimitris-georgopalis-greece.

Gouders, J. (2020). Corona also affects the European Union. Hollanda. Erişim tarihi: 30. 04. 2020. https://www.cartoonmovement.com/p/143.

Habermas, J. (2017). "Öteki" olmak "öteki"yle yaşamak: siyaset kuramı yazılar1 (9. Bask1). (İ. Aka, Çev.) İstanbul: Yapı Kredi Yayınları.

Hajjaj, O. (2020). Coronavirus and global economy. Ürdün. Erişim tarihi: 29.04. 2020. https://www.cartoonmovement.com/cartoon/64669.

Hobbes, T. (2019). Leviathan (20 Baskı). (S. Lim, Çev.) İstanbul: Yapı Kredi Yayınları.

Irwin, N. (2018, March 23). Globalization's backlash is here, at just the wrong time. Erişim tarihi: $01 . \quad 03.2020 . \quad$ The New York Times: https://www.nytimes.com/2018/03/23/upshot/globalization-pain-and-promise-for-richnations.html.

Jowitt, K. (1993). New world disorder: the leninist extinction. California: University of California Press. March 2020 tarihinde https://books.google.com.tr/books/about/New_World_Disorder.html?id=17YwDwAA QBAJ\&source $=\mathrm{kp} \_$cover\&redir_esc $=\mathrm{y}$ adresinden alındı.

Kaya, M. ve Acarlı, M. (2018). Cumhuriyet'in ilk yıllarına kadar Türkiye'de karikatürün tarihsel gelişimi. Millî Kültür Araştırmaları Dergisi, 127-133.

Lapshina, K. (2020). Quarantine heroes. Erişim tarihi: 30. 04.2020. https://scotscoop.com/cartoon-quarantine-heroes/.

Mahar, I. (2020, Nisan 22). Impact of Covid-19 on global economy structure. Erişim tarihi: 25. 04. 2020. moderndiplomacy: https://moderndiplomacy.eu/2020/04/22/impact-of-covid19-on-global-economy-structure/.

Martinera, A. (2020). Crisis of rich and poor. Küba. Erişim tarihi: 30. 04. 2020. https://www.cartoonmovement.com/cartoon/6115.

Matzo, M., ve Miller, D. (2009). Humor and death: A qualitative study of The New Yorker cartoons (1986-2006). Palliative \& supportive care, 7(4), 789-790. doi:10.1017/S1478951509990496.

NTV. (2020, Nisan 9). https://www.ntv.com.tr/ekonomi/corona-virus-sebebiyle-yarim-milyarkisi-daha-yoksullasabilir,wIBVk7iXxUyQ6iJ8LJUk9Q. Erişi tarihi: 25. 04. 2020. NTV:https://lms.gelisim.edu.tr/Video/New/09B0994AFB8E2A7F4AD035CB1DA311 63. 
Özocak, G. (2011). Türkiye'de Siyasi iktidarın mizahla imtihanı: İfade özgürlüğü ve karikatür. TBB Dergisi (259-294).

Rahma, A. (2020). International economy. Corona and the economic crisis. Türkiye.Erişim tarihi: 29. 04. 2020. https://www.cartoonmovement.com/cartoon/66330.

Ramirez, M. (2020). Coronavirus-is-under-control-trust-us. Amerika Birleşik Devletleri. Erişim tarihi: 26. 04. 2020. https://www.ocregister.com/2020/02/03/coronavirus-isunder-control-trust-us-political-cartoons/.

Samuelson, R. J. (2000, January 4). Growing market offers huge potential - But Also peril: Globalization's double edge. Erişim tarihi: 01. 03. 2020. The New York Times: https://www.nytimes.com/2000/01/04/news/growing-market-offers-huge-potentialbut-also-peril-globalizations.html.

Taylor, P. (2020, Mart 25). Coronavirus brings out best (and worst) in world leaders. Erişim tarihi: 15. 04. 2020. Politico: https://www.politico.eu/article/coronavirus-brings-outbest-and-worst-in-world-leaders/.

The Guardian. (2020, Nisan 12). After coronavirus: how will Europe rebuild? Erişim tarihi: 25. 04. 2020. The Guardian: https://www.theguardian.com/world/2020/apr/12/aftercoronavirus-how-will-europe-rebuild.

Topuz, H. (1997). Başlangıcından bugüne dünya karikatürü. İstanbul: İnk1lap Kitabevi.

Worldometers. (2020, Mayıs 11). Covıd-19 coronavırus pandemıc. Erişim tarihi: 11. 05. 2020. worldometer: https://www.worldometers.info/coronavirus/. 